Joseph A Clougherty

Tomaso Duso

\title{
Using Rival Effects to \\ Identify Synergies and Improve Merger Typologies
}

Discussion Paper SP II 2010-13

September 2010

Social Science Research Center Berlin (WZB)

Research Area:

Markets and Politics

Research Unit:

Competition and Innovation

http://www.wzb.eu/mp/win

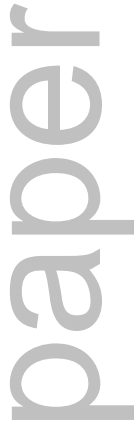

E-mail: duso@wzb.eu 
Joseph A Clougherty and Tomaso Duso

Using Rival Effects to Identify Synergies and Improve Merger Typologies Discussion Paper SP II 2010-13

Wissenschaftszentrum Berlin für Sozialforschung (2010)

Social Science Research Center Berlin (WZB)

Research Area:

Markets and Politics

Research Unit:

Competition and Innovation
Wissenschaftszentrum Berlin für Sozialforschung gGmbH (WZB)

Forschungsschwerpunkt:

Märkte und Politik

Abteilung:

Wettbewerb und Innovation

Reichpietschufer 50, D-10785 Berlin

Telefon: +49 30 25491-0, Fax: +49 30 25491-440

http://www.wzb.eu 


\section{Abstract}

The strategic management literature has found it difficult to differentiate between collusive and efficiency-based synergies in horizontal merger activity. We propose a schematic to classify mergers that yields more information on merger types and merger effects, and that can, moreover, distinguish between mergers characterized largely by collusion-based synergies and mergers characterized largely by efficiency-based synergies. Crucial to the proposed measurement procedure is that it encompasses the impact of merger events not only on merging firms - as is custom - but also on non-merging competitor firms (the rivals). Employing the event-study methodology with stock-market data on samples of large horizontal mergers drawn from the US and UK (an Anglo-Saxon sub-sample) and from the European continent, we demonstrate how the proposed schematic can better clarify the nature of merger activity.

Running Head: Using Rival Effects

Keywords: acquisitions, event-study, mergers, research methods, rivals, synergy

\section{Zusammenfassung}

Die Literatur über strategisches Management hatte bisher Schwierigkeiten, zwischen wettbewerbsschädlichen und Effizienz steigenden Synergien bei horizontalen Zusammenschlüssen $\mathrm{zu}$ differenzieren. Wir schlagen einen konzeptionellen Rahmen vor, um Fusionen zu klassifizieren, welcher mehr Informationen sowohl über die Fusionstypologie als auch über die Wirkung von Zusammenschlüssen entschlüsselt und welcher eine klare Abgrenzung zwischen wettbewerbsschädlichen und wettbewerbsfreundlichen Fusionen erlaubt. Fundamental für diesen konzeptionellen Rahmen ist, dass er nicht nur die Wirkung der Fusion auf die fusionierenden Unternehmen (was typisch in der Literatur ist) umfasst, sondern auch ihre Wirkung auf die Rentabilität der Wettbewerber. Wir wenden eine Ereignisstudienmethode mit Aktiendaten an, um unsere Kategorisierung empirisch umzusetzen. Im Vergleich einer Stichprobe von Fusionen in der angelsächsischen Welt (US und Großbritannien) mit Fusionen zwischen kontinentaleuropäischen Firmen zeigen wir, wie unsere Methodologie hilfreich sein kann, die Art der Fusionsaktivitäten zu identifizieren.

\footnotetext{
* Corresponding author. We wish to thank Jay Barney, Laurence Capron, Sayan Chatterjee, Wilbur Chung, Dave King, and Jo Seldeslachts for helpful discussions; participants at the University of Illinois at Urbana-Champaign 'Organizational Behavior' seminar for helpful comments; Claudia Baldermann, Constanze Quade and Jennifer Rontganger for excellent research assistance. Tomaso Duso gratefully acknowledges financial support from the Deutsche Forschungsgemeinschaft through SFB/TR 15.
} 


\section{Introduction}

A vast amount of literature within strategic management has employed the event-study methodology (combined with either stock price or accounting data to capture profitability) to examine merger and acquisition (M\&A) performance - see the extensive reviews by Datta, Pinches and Narayanan (1992), King, Dalton, Daily and Covin (2004), and Haleblian, Devers, McNamara, Carpenter and Davison (2009). This research has yielded a number of different insights concerning the merits of merger activity - i.e., M\&As generally benefit target firms but represent break-even propositions for acquirer firms - and concerning the drivers of M\&A performance: e.g., mergers that involve related firms (Rumelt, 1974; Palepu, 1985; Prahalad \& Bettis, 1986; Singh \& Montgomery, 1987; Flanagan, 1996), integration processes (Haspeslagh \& Jemison,1991; Pablo,1994; Larsson \& Finkelstein, 1999), and acquirer experience (Hitt, Harrison \& Ireland, 2001; Vermeulen \& Barkema, 2001; Barkema \& Schijven, 2008) are potentially more likely to improve performance. A consistent assumption throughout the literature is that a successful - or synergistic - M\&A is one that generates enhanced profitability for merging firms: by merging firms, we refer to the combined acquirer and target (Barney, 1988; Datta, 1991; Lubatkin, 1987). Accordingly, synergistic mergers are simply those mergers that lead, for instance, to a net positive gain in the stock prices of merging firms (Michel \& Shaked, 1985; Weidenbaum \& Vogt, 1987; Moeller, Schlingemann \& Stulz, 2005).

Yet, a number of strategy scholars (e.g., Chatterjee \& Lubatkin, 1990; Lubatkin, 1983; Seth, 1990; Trautwein, 1990) have noted that two broad synergy types exist: collusive synergies (based on the market-power implications of reduced competition where prices and profits go up for all firms in a market) and efficiency-based synergies (based on a broader set of micro-foundations including the operational, managerial, financial and resource-sharing opportunities involved with merging two firms). ${ }^{1}$ Efficiency-based synergies accordingly refer to more than just simple cost-reductions, but also to synergies resulting from combining the resources and capabilities of merging firms. While 
Walter and Barney (1990) point out that market-power and efficiency represent the principal motivations behind horizontal merger activity, the researcher cannot distinguish between the different synergy types when strictly considering merging firm profitability. Namely, a positive abnormal return in the stock price of merging firms identifies the presence of synergies but cannot indicate whether these synergies are largely collusive or efficiency based. The inability to separate synergy types led, for instance, to Chatterjee (1986) dropping all the horizontal M\&As from his empirical study in order to eliminate the effect of collusive synergies - since non-horizontal mergers involve minimal market-power - and concentrate on efficiency-based synergies. Yet, such a tactic is drastic in that many horizontal M\&As clearly involve efficiency-based synergies. Even more troubling is the trend in organizational scholarship - noticed and empirically refuted by Oxley, Sampson and Silverman (2009) - to completely neglect collusive synergies as a relevant and vital outcome of merger activity. The proclivity of scholarship to either omit horizontal merger activity from study or neglect the potential role of collusive synergies is partly due to the inability to differentiate between horizontal mergers that are largely efficiency or collusion based.

Our aim is to propose a theory-based quantitative means to classify M\&A activity that yields more information on actual merger types; thus, our contribution involves the advancement of measurement procedures. In particular, we provide a methodological approach for future strategic management research to more finely delineate between different merger types. Fundamental to our proposed methodological approach is the necessity to consider the impact of merger events on both merging firms (custom in the literature) and non-merging rival firms (not custom in the literature). Accordingly, we extend and improve upon the traditional measurement procedure from the strategy literature where researchers simply consider value changes in merging firms in order to determine the nature of merger activity (e.g., Lubatkin, 1987; Cannella \& Hambrick, 1993; Lubatkin, Srinivasan and Merchant, 1997). We do this by taking into account structural insights from industrial 
organization (IO) theory regarding the impact of strategic actions on the profitability and value of competitor firms, and by enhancing the crude conceptualizations in IO concerning efficiency with richer theories from strategic management. In this vein, McWilliams, Soegel and Teoh (1999) observe (and are concerned in their empirical context) that merger events can affect competitor firms - see Oxley et al. (2009) for an assessment of how rare it is in the strategic management literature for researchers to examine rival effects. ${ }^{2}$ Moreover, by simultaneously considering the reactions of merging and rival firms to M\&A transactions, we are able to show that collusion-based synergies (where rivals gain from the merger event) are fundamentally different from efficiencybased synergies (where rivals are harmed by the merger event). Thus by employing our proposed approach to consider both merging firms and non-merging rival firms, the researcher can distinguish between mergers largely driven by collusive synergies and mergers largely driven by efficiency-based synergies. In short, considering rival effects - in combination with the strategic management literature's traditional focus on acquirer and target profitability - yields critical information on the types of mergers being proposed.

Beyond the heuristic benefits of generating a means for future research to better distinguish between different merger types, our proposed schematic responds to additional calls in the organizational literature. First, Ketchen, Boyd and Bergh (2008: 646) note that "researchers ... [have] ... struggled with operationalizing the attributes of competitive advantage". In this vein, we follow up on Hitt et al.'s (2001: 58) pinpointing of what distinguishes efficiency-based synergy "creation of synergy results in a competitive advantage for the firm" - by factoring into our schematic the only location where competitive advantage can be detected: rival effects. Second, we respond to Chatterjee's (1986) early call to build an analysis encompassing the impact of M\&As on both merging and rival firms. Chatterjee (1992: 269) noted the potential for a schematic when he surmised that "if we simultaneously consider the stock price reactions of the rival and [merging 
firms] then we can uniquely determine the capital market's expectations about the ... takeover". Thus the seeds - efficiency-based synergies generate a competitive advantage, and the relevance of considering rival effects - of such an identification scheme have been present in the literature for some time, but have yet to be developed into a full-fledged methodological framework to measure the nature of merger activity.

In order to support our main aim - provide a measurement procedure that factors the impact of horizontal mergers on both merging and rival firms in order to improve our understanding of M\&A activity - we structure the remainder of the paper as follows. First, we discuss the methodological, conceptual and theoretical foundations behind our proposed measurement procedure. Second, we lay out the methodological schematic by presenting the taxonomy of four merger types. Third, we empirically demonstrate the relevance of the schematic by employing the event-study methodology with stock price data in a comparison of US and UK (Anglo-Saxon) merger activity with Continental-European merger activity. Fourth, we discuss the implications of the proposed schematic for the strategic management literature.

\section{Methodological \& Conceptual Foundations}

In proposing a methodological approach that yields more information on the nature of merger activity, we extend and enhance the approach that has often been employed in the strategy literature. The pre-existing literature would generally focus on the impact of a merger event on the value and profitability (whether that be measured by stock-price effects, accounting data, or other measures) of merging firms (e.g., Lubatkin, 1987; Cannella \& Hambrick, 1993; Lubatkin et al., 1997). Accordingly, a value-enhancing (or synergistic) merger would be indicated by a positive profit effect on merging firms, while a value-decreasing merger would be indicated by a negative profit effect on merging firms (Michel \& Shaked, 1985; Weidenbaum \& Vogt, 1987; Moeller, et al., 2005). ${ }^{3}$ While 
many studies would treat the profit-effect on merging firms as a continuous variable, Table 1 illustrates the simple taxonomy employed to characterize the nature of merger activity.

Insert Table 1 about here

We attempt to improve upon this simple empirically-based methodological framework for detecting merger type by adopting basic insights from the theory of industrial organization (IO) and enhancing these spartan IO theoretical models with richer insights from strategic management theory. The IO field's primary focus is the nature of competition (prices and quantities) in imperfectly competitive markets—markets that exhibit a finite number of competitors, rivalry, and most importantly - strategic interaction between firms (Tirole, 1992). Moreover, strategic interaction between firms in imperfectly competitive markets suggests direct links between the actions of one firm and the ultimate profitability of competitor firms (Porter, 1985). Interdependence forces firms to adapt their market strategies when competitor firms take strategic actions (Chen, 1996), and has direct implications with regard to identifying the two types of mergers we focus on here: collusionbased and efficiency-based synergistic mergers.

While relatively rich modeling tools have been employed to factor the nature of competition and strategic interaction, efficiency effects in IO models have still largely been represented by very simplistic reductions in marginal cost. Furthermore, the IO literature essentially 'black boxes’ efficiency effects by not analyzing in depth the source of these efficiency gains. It is in this realm where integrating the IO theoretical framework with the strategic management literature is particularly useful in improving the theoretical underpinnings of our proposed merger schematic. In particular, the simplistic IO idea that efficiency-based gains derive strictly from cost reductions can be understood as a reduced form specification that actually results from more complex processes: 
e.g., via the combination and integration of firm specific resources and capabilities (Barney, 1986; Dierickx \& Cool, 1989; Peteraf, 1993)—see Boone, 2006 for a rare example of IO theoretical work influenced by strategic management insights regarding resource accessing. Furthermore, while motivating the existence of efficiency-based synergies with more complex managerial theories, we can still use the straightforward logic of IO models to elicit the nature of horizontal merger activity: efficiency-based synergies, being merger specific, increase the profitability of merging firms but decrease the profitability of rival firms (Farrell \& Shapiro, 1990).

The IO framework also incorporates the presence of collusion-based mergers. The change in market structure brought about by a merger of two firms forces all firms in the market to reoptimize their market strategies. Given the reduced rivalry in the market due to the presence of fewer competitors, higher prices and profits result due to a contraction in aggregate output (Salant, Switzer \& Reynolds, 1983; Denekere \& Davidson, 1985; Perry \& Porter, 1985; and Farrell \& Shapiro, 1990). Following in this tradition, Gimeno and Woo (1999: 246) state that rivalry (i.e., more competitors) "is commonly reflected in decreased prices for the services provided by a firm". Gimeno and Woo go on to empirically support that a reduction in competition generally leads to higher prices and higher profits for firms in a market. One can even further specify the dynamics involved with collusive mergers under the two stock models in IO of imperfect competition: strategic competition over quantities (Cournot), and strategic competition over prices (Bertrand). In particular, merging firms reduce production and rivals increase production - though to a lesser degree than the merging firms' reduction - when quantity is the strategic variable (see Zhang and Gimeno (2010) for a representation of this dynamic). Further when price is the strategic variable, merging firms raise prices (or equivalently contract production) and rivals - to a lesser degree - raise prices (or equivalently contract production). In short, collusion-based mergers enhance the profits of 
both merging firms and rival firms by altering the market structure and eliciting accommodating responses by all firms in the market.

While the opening passages and the above discussion indicate that rival effects can help differentiate between the two M\&A types where merging firms gain (collusion-based and efficiencybased synergistic mergers), it is apparent that such mergers do not represent the full set of merger types. As is abundantly clear from the prescriptive literature advising firms not to engage in acquisition activity (e.g., Lubatkin et al., 1997; Lubatkin \& Lane, 1996; Sirower, 1997), many M\&As result in merging firms destroying value: i.e., negative profitability effects, as represented by the 'value-decreasing' mergers in Table 1. As Bergh (1997) notes, many value-decreasing mergers ultimately lead to divestitures and a damaged reputation for the acquiring firm and its managers. We will break down these value-decreasing mergers into two types: non-synergistic (where merging firms lose but rivals gain) and pre-emptive (where both merging firms and rivals lose). Nevertheless, non-synergistic and pre-emptive mergers can both be nested within an enhanced IO-based theoretical framework. For instance, by introducing uncertainty into a standard merger model, mergers which ex-ante seem to be profitable on average might end up being unprofitable if the expected efficiency-based synergies are not realized (Amir, Diamantoudi \& Xue, 2009). In such situations, non-synergistic mergers (which enhance rival firm profits) may manifest. Furthermore, enhancing the basic IO model to encompass endogenous merger decisions might lead to situations where mergers are not profitable for merging firms, yet it is even worse to be an outsider (Fridolfsson \& Stennek, 2005). In such situations, pre-emptive mergers (where both merging and rival firms lose value, but merging firms lose less) may manifest: i.e., merging firms pre-empt an even worse situation.

In sum, basic insights from the theory of industrial organization rest behind our proffered methodological schematic for delineating the nature of merger activity. Further, we can improve 
upon the crude conceptualization of efficiencies in IO theory by embracing richer theories from strategic management on leveraging the resources and capabilities of two merged firms in order to create competitive advantage. Drawing from these different traditions forms a robust theoretical framework with stronger conceptual foundations that allows more confidence in generating a merger schematic that advances measurement procedures regarding merger activity. In particular, simultaneously factoring the impact of a merger on the profits of merging and rival firms provides insight on the true nature of merger activity.

\section{Taxonomy of Merger Activity}

In order to fully factor how mergers impact the profitability of merging firms and nonmerging rivals, it helps to now build our taxonomy of four merger types. While the preceding discussion outlining the methodological foundations (the pre-existing empirical approach in strategy research to measuring merger performance and categorizing merger activity) and conceptual foundations (IO theory enriched with strategic management theory on M\&As) sets the basis for our proposed methodological approach, the presentation of the four merger types is essential in order to illuminate our proposed schematic of merger outcomes. Table 2 illustrates the proposed taxonomy of four merger types with respect to their varied effects on merging and rival firms.

Insert Table 2 about here

First, a long-standing rationale behind horizontal mergers is the elimination of competitors and facilitation of collusion amongst remaining firms (e.g., Porter, 1985; Stigler, 1964). The core dynamic behind these mergers is that the actions by merger insiders to increase prices and/or reduce output push the overall prices in the market up to the benefit of rivals. Hence, collusive transactions 
are beneficial to merger insiders (acquirers and targets) and outsiders (rivals), but come at the expense of suppliers and customers. For instance, the $\$ 50$ billion combination of Total-Fina and Elf-Aquitaine eliminated direct competition between these two large French petroleum companies, and yielded gains for both the merging firms and their rivals (see the Appendix for this and other examples of collusive mergers). Here, merging firms and rivals are competitive complements: the competition reduction leads to increased market power which enhances merging firm and rival firm profits. As an aside, the collusive elements of horizontal mergers were considered by many scholars (e.g., Chatterjee \& Lubatkin, 1990; Lubatkin, 1983; Seth, 1990) to be a unique synergy source (along with operational) for related mergers and, thus, one of the reasons why related mergers may outperform unrelated mergers. Accordingly, mergers falling in the northwest quadrant of Table 2 can be considered collusion-based synergistic mergers.

Second, the most widely cited rationale behind horizontal mergers is the search for efficiency-based synergies that can be pursued via scale and scope economies, as well as via skill and resource sharing between merging firms (Walter \& Barney, 1990). Accordingly, M\&As that reduce costs for merging firms by any metric - scope, scale, or buyer-power - are synergistic mergers. Based on the work conceptualizing industries as being characterized by a degree of resource heterogeneity and immobility (Barney, 1991), management research has moved beyond a focus on cost-based synergies to embrace a richer consideration of synergies with M\&As representing a means to purchase resources that could not otherwise be accessed (Barney, 1986; Dierickx \& Cool, 1989; Peteraf, 1993). More specifically, acquisitions provide bidders with new products, assets and skills which may be used to serve both new and pre-existing customers. For instance, Capron (1999) considers how resource redeployment post-acquisition can enhance M\&A performance. In this vein, Hitt et al. (2001: 82) argue that the joining of "complementary resources between an acquiring and acquired firm can create synergies that, in turn, generate a competitive advantage for the firm over 
its competitors". As they infer, efficiency-based synergistic mergers are fundamentally different to collusion-based synergistic mergers in that rivals indicate negative - not positive - profit-effects for such mergers.

With efficiency-based synergistic mergers, rival firms and merging firms represent competitive substitutes: the M\&A involves the joining of resources and capabilities that gives merging firms an advantage vis-à-vis rivals, thus the M\&A represents a competitive threat to rivals. It is important to underscore again that we do not restrict efficiency-based synergies to merger induced reductions in cost structure. In keeping with the richer strategic management theories, we also include the leveraging of resources, complementarities and capabilities between merging firms, as well as mergers that result in substantial buyer power for merging firms. For instance, Boeing's 1997 acquisition of McDonnell Douglas (Hill, 2011: 302-307) represents a merger where the combination of resources (complementary product lines) yielded a competitive advantage vis-à-vis rival firms (e.g., Airbus)—see the Appendix for examples of other efficiency-based mergers. Accordingly, mergers falling in the southwest quadrant of Table 2 (where merging firms gain, but rivals lose) can be considered efficiency-based synergistic mergers.

Third, it is well understood that targets reap the majority of M\&A gains while acquirers usually break-even but often experience value losses (Andrade, Mitchell \& Stafford, 2001; King et al., 2004); moreover, sometimes acquirer value losses are so substantial that the net effect on the merging firms represents a loss (i.e., acquirer losses outweigh any potential target gains). Here, we highlight the existence of value-decreasing mergers: indicated by a net-negative change in profitability for merging firms. A number of explanations for the existence of such mergers have been posited: e.g., empire-building - managerial incentives to grow the company at shareholder expense (Mueller, 1969; Walsh, 1988; Weidenbaum \& Vogt, 1987); managerial-hubris - managerial expectations are systematically upward biased (Jemison \& Sitkin, 1986; Roll, 1986); as well as 
information processing constraints in the Simon (1957) tradition, and internal political games in the Pettigrew (1977) tradition. Further, when firms compete as competitive substitutes, value-decreasing mergers represent an opportunity for non-merging rivals. The M\&A does not involve sufficient joining of resources and capabilities, thus the merged firm has no advantage vis-à-vis rival firms. In fact, the internal integration challenges of such a merger (Birkinshaw, Bresman \& Håkanson, 2000; Larsson \& Finkelstein, 1999; Larsson \& Lubatkin, 2001) could encumber the firm in strategic competition - recall that managerial time and cognition come in limited quantities - to the advantage of rivals. For instance, the AOL/Time-Warner merger from 1999 involved substantial integration challenges that led to - even controlling for the burst in the dot-com bubble - substantial decreases in profitability for the merging parties, while providing a competitive advantage to more traditional media companies (e.g., Vivendi, CBS, Viacom, and others). These types of mergers are the reciprocal of efficiency-based synergistic mergers: just as a merger which enhances efficiency will threaten rivals, a merger which decreases the efficiency (or competitiveness) of merging firms represents a competitive boon to rivals. In short, the value-destroying nature of such mergers creates competitive opportunities for enhancing rival firm profitability and performance. Accordingly, mergers falling in the northeast quadrant of Table 2 (where merging firms lose, but rivals gain) can be considered non-synergistic mergers.

Fourth, some value-decreasing mergers actually generate competitive losses for both merging and rival firms. In this class of M\&As, the merging and rival firms can be considered competitive complements; i.e., the merger is value-decreasing for both parties. Such 'destructive' mergers were traditionally difficult to explain; though, recent research on the nature of pre-emptive mergers (e.g., Akdogu, 2003; Brito, 2003; Fridolfsson \& Stennek, 2005; Molnar, 2007) helps shed light on the dynamics behind some of these mergers. Essentially, if losing a target to a competitor means you would experience a substantial competitive loss, then it may make sense to over-bid and receive a 
negative return: i.e., the acquiring firm's losses are not as large as they would have been had they been an outsider to the merger. These pre-emptive mergers provide a logic as to why rational shareholder-valuing managers might pursue value-decreasing mergers. Furthermore, Molnar (2007) notes that when submitting a bid reveals negative news about an industry (e.g., the presence of cost or demand shocks), pre-emption results in a decreased aggregate value for the merging firms. For example, Kimberly-Clark's acquisition of Scott Paper in 1995 resulted in a loss for the shareholders of the two merging firms; yet in light of the declining nature of the paper goods industry, this M\&A yielded even greater losses to the rival firms not participating in the merger—see the Appendix for other 'pre-emptive' mergers. It should be pointed out that many mergers here (where the acquiring firms experience larger losses than rival firms) do not conform to the pre-emption premise; instead, these mergers must simply be considered value-destroying due to managerial failure of one kind or another. Nevertheless, we categorize M\&As that generate net-negative profitability changes for merging and rival firms as pre-emptive mergers even though that does not cover all the transaction types embedded in this category. Accordingly, mergers falling in the southeast quadrant of Table 2 (where merging and rival firms lose) can be considered pre-emptive mergers.

The above discussion shows how variations in the impact of transactions on merging and rival firms' profitability can provide an indication of the M\&A's true nature. However, it bears pointing out here that specific mergers will potentially involve elements of different merger types: e.g., many M\&As involve both efficiency-based and collusion-based elements (Kim \& Singal, 1993). Yet, the profit effect indicates which element dominates: the net effect. For example, an M\&A where merging firms elicit positive profitability effects may involve both collusive and efficiencybased synergies, yet if rivals elicit a negative profit effect then the efficiency-based elements of the transaction dominate the collusive elements. For instance, the efficiency-based Boeing/McDonnellDouglas pairing noted above also surely involved some collusive effects due to the reduction in 
competition; however, the efficiency-effects involved with the merger evidently swamped the collusive-effects. Likewise, if rivals elicit a positive profit effect then the collusive elements of the transaction dominate the efficiency-based elements. Accordingly, our schematic provides a direct means - factoring rival and merging firm effects - to disentangle mergers that are 'dominantly' collusion-based from mergers that are 'dominantly' efficiency-based mergers, and to disentangle the two value-decreasing merger types (non-synergistic and pre-emptive).

\section{Empirical Demonstration}

Our proposed schematic is general in that it is conceptually based on the transaction-induced profitability effects (i.e., the impact of the merger on value and profits) for merging and rival firms. Empirical operationalizations could accordingly use stock price data (both short-run and long-run event-windows) as well as accounting and survey-based data to capture the profitability and performance of the merger. Our own empirical demonstration will employ stock price data based on relatively long short-term windows. As McWilliams and Siegel (1997), McWilliams et al. (1999), and Haleblian et al. (2009) attest, the principal advantage of a short-term window approach is that stock price changes are better attributed to the event and less subject to confounding effects (i.e., keeping the window narrow ensures against the presence of other major events being the source of any abnormal return). Nevertheless, the advantage with longer event windows is that more information concerning the event can be impounded by the financial market: e.g., whether the executives of target firms will be retained post-acquisition (Bergh, 2001).

In our methodological context, it is important to expand the event-window beyond a very narrow 3-days (from 1 day before until 1 day after the event), as we consider both the reaction of merging firms and rival firms to an event. It stands to reason that it will take more time to impound the effects of a merger on the stock prices of rival firms, as financial markets must first ascertain the 
nature of the merger itself, then calculate the nature of competition and rivalry in the market, and finally factor the impact of the merger on rival firms. While the above suggests extending the eventwindow beyond one day after the event, the potential for information leakages also suggests extending the event-window prior to the event. Information leakages are particularly pertinent given the nature of our merger sample: very large horizontal combinations that undergo an automatic antitrust vetting. Thus, the likelihood that information leaks to the market prior to the official merger announcement is quite high (e.g., Ellert, 1976). Beyond these intuitive rationales behind expanding the event-window, auxiliary empirical evidence suggests that the 56-day window (from 50 days before until 5 days after the event) yields the tightest correlation with the actual change in accounting-based profits earned by merging and rival firms in the three to five years subsequent to the merger. ${ }^{4}$

Using the cumulative abnormal return (CAR) for merging firms and rival firms over a 56-day window, we then classify particular M\&As into the four merger types illustrated in Table 2 . Notice that we consider the abnormal returns of merging firms (acquirer plus target) in order to sidestep the whole issue as to which of these two firms captures the majority of the transaction value (Singh \& Montgomery, 1987; Barney, 1988; Sirower, 1997; Andrade, et al., 2001; Moeller et al., 2005). While it is generally an important question as to whether the acquirer or target earns the majority of the value created by a merger (see Datta et al., 1992, King et al., 2004, and Haleblian et al., 2009 for reviews) the focus here is simply on whether the merger actually created value and not on who gets that value. Accordingly, each empirical observation represents a pairing between the two merging firms and the relevant set of rivals for the transaction. We also enlarge the proposed taxonomy to include an extra empirical category labeled 'no effect': cases where the CARs are not statistically different from zero (within one standard error around zero). 
The basic idea behind the event-study method employing short-run financial market data is that any event-induced change to the value and profitability of the focal firm(s) will be reflected in changes to the stock price of this firm (see McWilliams \& Siegel, 1997 for more details). Thus, we can graft our proposed schematic on to a sample of horizontal merger activity while employing the event-study methodology in order to delineate between different M\&A types. Therefore, when employing the event-study methodology with stock price data, we can classify mergers as follows:

- mergers that generate net-positive abnormal returns to merging firms (acquirers and targets) and a net-positive abnormal return to rival firms can be considered collusion-based synergistic mergers,

- mergers that generate net-positive abnormal returns to merging firms (acquirers and targets) and a net-negative abnormal return to rival firms can be considered efficiency-based synergistic mergers,

- mergers that generate net-negative abnormal returns to merging firms (acquirers and targets) and a net-positive abnormal return to rival firms can be considered non-synergistic mergers,

- mergers that generate net-negative abnormal returns to merging firms (acquirers and targets) and a net-negative abnormal return to rival firms can be considered pre-emptive mergers.

\section{Data}

Our sample captures large horizontal M\&As that occurred within the 1990-2002 period and affected European product markets. The sample was drawn from those merger transactions automatically analyzed by the European Commission (EC) for antitrust implications. ${ }^{5}$ The chief advantage to drawing our sample from the mergers analyzed by EC officials is that Commission experts have identified the relevant competitors (rivals) for every M\&A, thus yielding an accurate assessment of rival identity. The expert assessment of rival identity represents a particular strength of 
this sample, as much of the finance-based literature that analyzes the impact of mergers on rivals simply defines rivals as those firms sharing the same industry classification (e.g., Eckbo, 1983; Song \& Walkling, 2000; Fee \& Thomas, 2004). Yet sharing the same industry does not equate to actually competing against merging firms in a particular market; hence, the expert assessment of rival-identity allows assessing the effect of mergers on rivals much more precisely than most previous work. While Shahrur (2005) takes a novel approach by employing input-output account data in order to identify buyer and seller firms, this identification of customers, suppliers, and rivals is still based on industry classifications. Thus, rival-firm identification represents a substantial strength to our particular sample and approach. ${ }^{6}$

For the strict purpose of illustrating the heuristic benefits of our merger schematic, we will focus on two different sub-samples: one based on US and UK merger activity (Anglo-Saxon), and one based on intra-European merger activity that excludes merger participants from the UK (Continental European). To be specific, the Anglo-Saxon M\&As consist of transactions where either a US or UK firm was involved in the merger as either an acquirer or target, while ContinentalEuropean M\&As consist of transactions where both the acquirer and target hail from the European continent. Furthermore, we identified and obtained usable data (stock price information on the relevant acquiring, target and rival firms) for 58 Anglo-Saxon and 46 Continental-European transactions. Thus we were conscious to balance McWilliams and Siegel's (1997) recommendations elimination of observations with confounding events, and ensuring as large a sample as possible concerning the use of the event-study methodology in organizational research.

One of the crucial issues in event studies is the determination of the moment when the information about the merger hits the market (McWilliams et al., 1999). In line with standard practice (e.g., Banerjee \& Eckard, 1998), we define the merger announcement date to be the first day in which rumors about a particular merger appeared in the international press. Hence, for each of 
the mergers in our sample, we used 'Dow Jones Interactive' - a customizable business news and research product that integrates content from newspapers, newswires, journals, research reports and web sites - to identify the event date. ${ }^{7}$ The necessary stock market data for the relevant firms were downloaded from 'Datastream'. In particular, we collected daily stock returns $\left(R_{i, t}\right)$ and market values $\left(M V_{i t}\right)$ for all merging and rival firms, as well as information on a market return $\left(\mathrm{R}_{m, t}\right)$ for each firms' industry sector (where $i$ refers to the firm, $m$ to the specific sector, and $t$ to time).

\section{Event-Study Methodology}

With the above data at hand, we follow the standard stock market event-study methodology by calculating the abnormal returns corresponding to a merger announcement. The abnormal return for firm $i$ around the mergers' announcement day $t\left(A R_{i, t}\right)$ is defined as $A R_{i, t}=R_{i t}-\hat{R}_{i t}$, where $\left(\hat{R}_{i t}\right)$ is the return for the scenario in which the merger would not have been announced. This counterfactual variable is not observable and must therefore be estimated. Hence, by using the

market model, we first define the 'normal return' for each firm as $R_{i, t}=\alpha_{i}+\beta_{i} R_{m, t}+\varepsilon_{i, t}$, where firm 's stock return at time $t\left(R_{i, t}\right)$ is assumed to be proportional to a market return $\left(R_{m, t}\right)$ and $\varepsilon_{i, t}$ is an i.i.d. normally distributed error term. We then estimate this equation over a 240 -day trading period ending 60 days prior to the announcement date - while using the Scholes and Williams (1977) method. After obtaining estimates for the model's parameters $a$ and $\beta$, we can build the counterfactual estimate of the stock price in the event where the merger would not have been announced: $\hat{R}_{i t}=\hat{\alpha}_{i}+\hat{\beta}_{i} R_{m, t}$.

Following the literature, and to account for possible information leakages - which influence firm is return before (or after) the merger announcement - we define the CAR to be the sum of the daily abnormal returns within an event-window spanning from $\tau_{1}(50)$ days before the event to $\tau_{2}(5)$ 
days after the event: $C A R_{i, \tau_{1}, \tau_{2}}=\sum_{t=\tau_{1}}^{\tau_{2}} A R_{i, t}$. Since our unit of observation is the merger, we generate an aggregated abnormal return for the combined merged entity (acquirer and target) as well as for the combined rivals for a given transaction by respectively taking the weighted average of the merging firms' and rival firms' CARs using their market value as a weight. Thus, we calculate the average CARs (ACAR) for the merging firms $(\mathrm{M})$ and rival firms $(\mathrm{R})$ involved in merger $j$ as follows:

$$
A C A R_{j, \tau_{1}, \tau_{2}}^{f}=\frac{\sum_{i=1}^{I_{j}^{f}} C A R_{i, \tau_{1}, \tau_{2}} * M V_{i t}}{\sum_{i=1}^{I} M V_{i t}} \quad f=M, R
$$

where $I_{j}^{f}$ is the number of merging - or rival - firms involved in merger $j$. Thus, the CARs for merging firms and rival firms represent weighted averages of the composite firms (see McWilliams et al., 1999 for more description of the event-study method).

Table 3 reports the mean CARs for all relevant firm types using our employed event-window of 56-days over the different merger samples (Continental-European, Anglo-Saxon and All Mergers). The sample means broadly conform to the well-established stylized facts (e.g., Andrade et al., 2001; King et al., 2004) concerning merger activity: targets reap substantial gains with positive and significant CARs, acquirers tend to break even by indicating CARs insignificantly different from zero, and merging firms as a whole generate slightly positive CARs.

Insert Table 3 about here

\section{Empirical Results}

Using our proposed schematic in conjunction with the stock-price measures obtained via the event-study method allows building tables that illustrate the merits of our methodological approach 
to classifying mergers. Table 4 presents the merger taxonomy based on the Anglo-Saxon mergers. Reflecting the importance of the proposed conceptual framework, Table 4 illustrates the nonnegligible presence of all kinds of mergers in the sample: i.e., collusion-based synergistic $(22.41 \%$ of the sample), efficiency-based synergistic (25.86\% of the sample), non-synergistic (15.52\%) and preemptive $(24.14 \%)$ all exist. Furthermore, $48.28 \%$ of the merging firm observations experience a significant positive CAR, whereas $44.83 \%$ experience a significant negative CAR.

Insert Table 4 about here

Moreover, we would like to compare this sample of Anglo-Saxon merger activity with another sample of mergers in order to illustrate the relevance of our merger schematic. Thus, table 5 presents the merger taxonomy based on the sub-sample of Continental-European merger activity. Notice that the Anglo-Saxon and Continental-European sub-samples yield very similar results with regard to how often merging firms' experience a significant positive CAR: 48.28\% for the AngloSaxon sample, and $47.83 \%$ for the Continental-European sample. If we were to have no information on rival effects - akin to the traditional approach in the strategic management M\&A literature - then we would argue that the M\&As in these two samples are generally identical in terms of synergistic tendencies; i.e., Anglo-Saxon and Continental-European M\&As appear to be equally synergistic. Yet factoring the impact of these mergers on rival firms (i.e. employing our proposed schematic) tells us quite a bit more. Collusion-based synergistic mergers represent $28.26 \%$ of the Continental-European sample, but only $22.41 \%$ of the Anglo-Saxon sample; further, efficiency-based synergistic mergers represent $17.39 \%$ of the Continental-European sample, and $25.86 \%$ of the Anglo-Saxon sample. In short, efficiency-based synergistic mergers are relatively more prevalent in Anglo-Saxon merger activity; and, collusion-based synergistic mergers are relatively more prevalent in Continental- 
European merger activity; though, it should be noted that these differences are only statistically significant at a tolerant 20\% level. ${ }^{8}$ Accordingly, the synergistic Anglo-Saxon mergers tend to be characterized less by collusive synergies and more by the attainment of efficiency-based synergies. Hence, Anglo-Saxon mergers appear to involve the optimal redeployment of resources between merging firms that actually leads to the creation of a competitive advantage vis-à-vis rivals, whereas the Continental-European mergers appear to simply require the reaping of benefits from the reduction of competition in a market.

Insert Table 5 about here

Comparing the Anglo-Saxon and Continental-European samples for the nonsynergistic/pre-emptive distinction also proves to be illustrative; though, the differences are again not statistically significant. We see that non-synergistic mergers - where the M\&A decreases the performance of merging firms and actually enhances rival firm performance - represent $19.57 \%$ of Continental-European merger activity, but only $15.52 \%$ of Anglo-Saxon merger activity. The relative scarcity of non-synergistic mergers in the Anglo-Saxon sub-sample is important, as these mergers indicate substantial failure on the part of managers. Furthermore, the broadly labeled pre-emptive mergers - where the managers of merging firms may be valuing shareholders by attempting to mitigate losses - represent $28.26 \%$ of Continental-European and $24.14 \%$ of Anglo-Saxon merger activity. Taking a closer look at the data to consider which M\&A events actually indicate smaller losses for merging firms as compared to rival firms (i.e., a truly pre-emptive result), we see that five of the Anglo-Saxon mergers and five of the Continental-European mergers were truly pre-emptive; thus, no substantial difference in the tendency to undertake pre-emptive mergers is indicated. 
In sum, the results from the empirical demonstration of our proposed schematic tentatively suggest that Anglo-Saxon mergers are more shareholder-valuing than Continental-European mergers. While Anglo-Saxon and Continental-European merger activity are equally synergistic in terms of merging firms' profitability (i.e., around $48 \%$ of the mergers in both samples indicate significantly positive abnormal returns), the synergistic Anglo-Saxon mergers are largely characterized by the attainment of efficiency-based synergies as compared to the ContinentalEuropean mergers which are more characterized by the attainment of collusive synergies. Furthermore, the Anglo-Saxon merger activity exhibits fewer non-synergistic mergers: where the M\&A generates losses for merging firms but, incredibly, gains for rival firms. It is imperative to underscore that such distinctions in the two samples of merger activity would be impossible to detect when employing the traditional approach of strictly focusing on the profitability of merging firms (e.g., acquirer and target). Only by employing our proposed schematic (where the researcher simultaneously considers merging firm and rival firm effects) can such distinctions be made.

\section{Implications}

We begin to address Chatterjee's (1986) call for a more rigorous conceptual framework on merger activity that embraces the full effects of merger events: i.e., the impact on both merging and non-merging rival firms. Moreover, the different competitive effects of M\&As on merging and rival firms drives the identification of the different merger types in our proposed schematic. If one were to assume that merger motives align with merger outcomes, then rival effects also help us differentiate between mergers where the motive is generally softer rivalry in a market (i.e., collusionbased synergistic mergers) and mergers where the motive is generally competitive in nature (i.e., efficiency-based synergistic mergers). In addition, rival effects help us differentiate between mergers where the motive is often hubris or empire-building in nature (i.e., non-synergistic mergers) and 
mergers where the motive tends to be rational and shareholder-valuing (i.e., pre-emptive mergers). Without considering rival effects, we simply could not make these distinctions. The efficacy of these distinctions underscores Oxley et al.'s (2009: 1322) point that “examining the effect of one firm's action on the abnormal returns earned by its rivals ... is quite novel in strategy research and ... can be usefully applied".

The sub-point regarding the importance of rival effects in helping better illuminate the nature of merger activity can be borne out further. As already noted, focusing strictly on merging firm performance does not allow teasing apart collusion-based synergistic mergers from efficiencybased synergistic mergers: both types positively impact merging firms, but only efficiency-based mergers negatively impact rival firms. Consider, for instance, how the managerial challenges involved with these two types of mergers are quite different: collusive mergers simply require the killing off of a competitor and the subsequent reaping of gains from reduced rivalry, while efficiency-based mergers require sophisticated integration of resource bundles a la Barney (1986) and Capron (1999) - integration so successful that rival firms find themselves at a disadvantage with regard to the merged entity. For example, our empirical demonstration tentatively indicates that Anglo-Saxon M\&As tend - relatively - to consist of more truly synergistic activity (i.e., efficiencybased mergers that generate a competitive advantage) than do Continental-European M\&As. Accordingly, by defining merger types in this fashion we gain insight into the potential managerial challenges involved with a specific merger transaction.

Furthermore, value-decreasing transactions that reduce merging firms' profitability and performance are often considered failures on the part of management due to empire-building, managerial-hubris or information-processing problems (Lubatkin, 1983). Hence, mergers that generate a net-negative impact on merging firms (e.g., a net-negative CAR) have traditionally been lumped into the value-decreasing merger category and considered the result of managerial failure. 
Yet pre-emptive mergers are fundamentally different from non-synergistic mergers. Pre-emptive mergers actually involve shareholder valuing management, but in this case management must engage in strategic actions (i.e., a merger) that decrease performance and profitability in order to protect shareholders from what would be a greater loss if the firm were left outside of merger activity. Taking rival effects into account allows distinguishing between these two fundamentally different merger types (non-synergistic and pre-emptive) with seemingly different managerial challenges.

Delineating merger type via a transaction's impact on both merging and rival firms may also help explain the mixed findings in the empirical literature concerning merger activity. The King et al. (2004) study clarifies the inability of the empirical literature to consistently and repeatedly converge upon the drivers of M\&A performance. Accordingly, the authors conclude that a missing moderator of merger performance exists, as "researchers simply may not be looking at the 'right' set of variables as predictors" (King et al., 2004: 197). Our proposed schematic might proffer a solution to this puzzle as it could explain the inconsistency in the empirical literature: i.e., identify one of those missing moderators. In particular, the predictors of M\&A success (relatedness, experience, integration, etc.) may fundamentally differ for different merger types, thus explaining the inconsistency in the results concerning M\&A performance drivers. For instance, acquisition experience could be fundamental for efficiency-based mergers that seek to re-deploy resources in an optimal manner, but acquisition experience may be ineffectual for collusive mergers that simply seek the reduction of competition in a market. Thus, we anticipate a number of potential future research avenues where the proposed schematic can be employed.

Most importantly, we hope that our proposed schematic will be employed by future researchers desiring to elicit a finer classification of the nature of merger activity. One can first imagine similar comparisons of merger activity in different geographic regions being of interest to corporate governance (e.g., Aguilera \& Jackson, 2003; Gugler, Mueller \& Yurtoglu, 2004) and 
institutionalist scholars (e.g., Hall \& Soskice, 2001), as the existence of substantially different merger types in different regions and countries would support the merits of focusing on the presence of cross-national institutional heterogeneity. For instance, the evident differences in our two subsamples of merger activity potentially bear out Haleblian's (2009) observation that macro-level factors - like national culture and legalistic traditions - may influence the nature of merger activity.

Most importantly, we anticipate that our merger schematic can replace the proclivity of the strategy literature to simply consider the impact of a merger on the performance (often captured by the event-study method) of merging firms. Thus instead of focusing simply on the drivers of merging firms' value and profits, future empirical scholarship with theoretically generated hypotheses could consider the factors determining the different merger types. Such research would necessarily involve the coupling of our proposed approach to classifying merger activity along with multinomial logit analysis (e.g., Long, 1987) in order to properly deal with the categorical nature of the dependent variable. While the strategic management literature has customarily employed the abnormal returns of merging firms as a dependent variable and then considered the various drivers of merger value, the implicit argument here is that such efforts will involve spurious causal inferences in light of the measurement error involved with simply considering the performance of merging firms. Only by better measuring the nature of merger activity (i.e., considering the impact of the merger on rival firms as well as merging firms) can organizational researchers truly converge on the actual drivers of M\&A performance and outcomes.

\section{Conclusion}

Motivated by the inability in the strategic management literature to differentiate between collusive and efficiency-based synergies, we build a methodological framework that yields more information on merger type. The proposed schematic departs from the customary approach in the 
empirical literature to simply focus on how M\&As impact merging firms (i.e., the acquirer and target) by also considering how mergers impact rival firms. In particular, by analyzing rival firm effects - in combination with the traditional focus on merging firm effects - we can differentiate between collusion-based and efficiency-based synergistic mergers (the two value-increasing M\&A types for merging firms) and between non-synergistic and pre-emptive mergers (the two valuedecreasing M\&A types for merging firms). Simply put, the reaction of rival firms to merger events yields critical information on the nature of the proposed transaction. We empirically demonstrate the relevance of the proposed schematic on merger samples drawn from the US and UK (Anglo-Saxon) and the European continent, and show that differences in Continental-European and Anglo-Saxon merger activity only become manifest once rival effects are considered. Thus, we urge strategic management scholarship to begin to heed Chatterjee's $(1986,1992)$ early call to consider rival effects, as the impact of a merger on rival firms - in combination with the impact on merging firms - provides salient information regarding the true nature of the transaction. 


\title{
Notes
}

\begin{abstract}
${ }^{1}$ Some scholars (e.g., Trautwein 1990) consider buyer-power mergers (which lower merging firms' input prices) to reflect collusive-synergy. We consider these mergers to be efficiency-based as the impact of such M\&As is lower costs for merging firms. Thus in our context, collusive mergers significantly lower competition in a horizontal market, and potentially lead to reduced rivalry and greater pricing power vis-à-vis customers.
\end{abstract}

${ }^{2}$ McGahan and Silverman's (2006) study on how granted-patents impact rival-firms, and Clougherty and Duso's (2009) contention that rival firms generally gain from mergers represent two exceptions to this point. Yet, Fosfuri and Giarratana (2009) observe that the same neglect for rival-effects is present in the marketing literature.

${ }^{3}$ It should be noted that the survey method has been employed by many organizational researchers in order to determine merger type. Yet empiricists have been concerned about the potential for measurement error and biases when it comes to relying on respondent opinion (Newbert, 2007). For instance, Bruner (2002) notes that managers overwhelmingly find their own firms to engage in synergistic M\&A activity, despite the fact that such strategies are break-even propositions at best. ${ }^{4}$ We were able to collect balance sheet data from Standard \& Poor's 'Global Vantage' database for a sub-sample of our merging and rival firms. This allowed the creation of a post-merger profitability measure for both merging and rival firms. In particular, the measure takes the reported profit levels over total asset levels for merging and rival firms, and then compares that measure with a counterfactual measure of this variable (i.e., what that measure should be in the absence of the merger event). We define the counterfactual in a manner akin to Duso, Gugler and Yurtoglu (2010) where they use the development of profits over total assets for the median firm (in terms of profitability) in the same 3-digit SIC industry that merging and rival firms operate. We then calculate the development of profits from three to five years after the merger in order to control for transitory post-acquisition integration challenges (Clougherty \& Moliterno, 2010). When estimating a table of correlation coefficients, we find that the abnormal returns calculated using a longer $(50,5)$ eventwindow indicate a much tighter - and statistically significant - relationship with post-merger profitability than do shorter event-windows. Thus, the longer short-term event-window appears to indicate greater construct validity, as it converges on another operationalization (accounting-based profit effects) that theory suggests it should be similar with. 
${ }^{5}$ EU merger regulations mandate notification when the combined aggregate worldwide turnover of merging firms exceeds 5 billion Euros or when the combined aggregate EU-wide turnover of merging firms exceeds 250 million Euros. Therefore, these M\&As have undergone a mandatory investigation by the EC - an investigation automatically triggered because the merger size exceeded the notification thresholds. Thus by not picking up the small mergers that do not require notification, the sample is characterized by relatively large horizontal merger activity. However, the robustness of the results to various sub-samples based on different antitrust-scrutiny levels suggests that the sample is not defined by anti-competitive mergers where collusion-based motivations would consistently prevail. Note also that Lubatkin et al. (1997) find that changes in antitrust scrutiny levels do not appear to change the nature of merger activity in an economy as measured by cumulative abnormal returns.

${ }^{6}$ See Duso, Neven and Röller (2007), Clougherty and Duso (2009), and Duso et al. (2010) for examples of empirical studies that draw a merger sample from the EC for similar benefits.

${ }^{7}$ In order to ensure the accuracy of these dates, we obtained the announcement dates from Thomson Reuters SDC database for a large sub-sample of our mergers. These dates correspond for almost all of our mergers, and the difference is minimal for the few mergers where the dates do not exactly correspond.

${ }^{8}$ The lack of statistical significance is in part due to the limited sample on which we run our tests for differences in means, and is also due in part to the nature of the merger taxonomy as differences between samples will not be huge. 
Appendix

Sample of Merger Activity sorted by Classification of Merger Type

\begin{tabular}{|c|c|c|c|}
\hline Acquirer & Target & Sample & Year \\
\hline \multicolumn{4}{|c|}{ Collusion-Based Synergistic Mergers } \\
\hline Cyanamid & Shell & Anglo & 1993 \\
\hline Crown Cork \& Seal & Carnaudmetalbox Sa & Anglo & 1995 \\
\hline Coca-Cola Enterprises & Cadbury Schweppes & Anglo & 1996 \\
\hline Guinness & Grand Metropolitan & Anglo & 1997 \\
\hline Worldcom & $\mathrm{MCI}$ & Anglo & 1997 \\
\hline Dow Jones & General Electric & Anglo & 1997 \\
\hline Commercial Union Plc & General Accident Plc & Anglo & 1997 \\
\hline Ingram & Tech Data & Anglo & 1998 \\
\hline Bp Amoco Plc. & Atlantic Richfield & Anglo & 1999 \\
\hline Dow Chemical & Union Carbide & Anglo & 1999 \\
\hline Unilever PLC & Bestfood & Anglo & 2000 \\
\hline United Airlines & US Airways Group Inc. & Anglo & 2000 \\
\hline H.J. Heinz Company & CSM NV & Anglo & 2001 \\
\hline Fiat & Alcatel & Cont. & 1990 \\
\hline Viag & Continental Can & Cont. & 1991 \\
\hline Nestle' & Eaux Vittel & Cont. & 1992 \\
\hline Mannesmann & Hoesch & Cont. & 1992 \\
\hline Schneider Electric S.A. & AEG A.G. & Cont. & 1994 \\
\hline Man & Ingersoll Rand & Cont. & 1994 \\
\hline Thyssen Stahl & Acciai Speciali Asti & Cont. & 1994 \\
\hline Saint Gobain & Hoechst Wacker & Cont. & 1996 \\
\hline Total Fina & Elf Aquitaine & Cont. & 1999 \\
\hline Framatome & Siemens & Cont. & 2000 \\
\hline Metsä-Serla Corporation & Modo & Cont. & 2000 \\
\hline Stinnes AG (E.ON AG) & Holland Chemical & Cont. & 2000 \\
\hline Fabricom & GTI & Cont. & 2001 \\
\hline \multicolumn{4}{|c|}{ Efficiency-Based Synergistic Mergers } \\
\hline Digital Equipment Int. & Mannesmann & Anglo & 1991 \\
\hline Du Pont & Imperial Chemical Ind. & Anglo & 1992 \\
\hline Asea Brown Boveri & Trafalgar Hse & Anglo & 1992 \\
\hline Fletcher Challenge & Methanex & Anglo & 1993 \\
\hline British Telecom & MCI (Ii) & Anglo & 1997 \\
\hline Boeing & McDonnell Douglas & Anglo & 1997 \\
\hline Exxon Corporation & Mobil Corporation & Anglo & 1999 \\
\hline Astra & Zeneca & Anglo & 1999 \\
\hline ACCOR S.A. & The BLACKSTONE & Anglo & 1999 \\
\hline Alcan Aluminium Lcd. & Alusuisse Lonza & Anglo & 1999 \\
\hline Emc & Data General & Anglo & 1999 \\
\hline Boeing & Hughes Electronics & Anglo & 1999 \\
\hline Ashland & Superfos & Anglo & 1999 \\
\hline Cendant Corporation & Galileo International & Anglo & 2001 \\
\hline Flextronics International & Xerox Corporation & Anglo & 2001 \\
\hline
\end{tabular}




\begin{tabular}{|c|c|c|c|}
\hline Acquirer & Target & Sample & Year \\
\hline \multicolumn{4}{|c|}{ Efficiency-Based Synergistic Mergers } \\
\hline Alcatel Cable S.A. & Aeg Kabel & Cont. & 1991 \\
\hline Orkla As & Volvo & Cont. & 1995 \\
\hline Fortis & Abn-Amro Bank & Cont. & 1997 \\
\hline Roche & Boehringer Mannheim & Cont. & 1997 \\
\hline Linde AG & AGA AB & Cont. & 1999 \\
\hline Ab Volvo & Scania $\mathrm{Ab}$ & Cont. & 1999 \\
\hline Vivendi S.A. & Canal+ S.A. & Cont. & 2000 \\
\hline UPM-Kymmene & Haindl & Cont. & 2001 \\
\hline \multicolumn{4}{|c|}{ Non-Synergistic Mergers } \\
\hline Ingersoll Rand Co. & Dresser Inc. & Anglo & 1991 \\
\hline Uap & Transatlantic HDG. & Anglo & 1991 \\
\hline Coca Cola & Carslberg A/S & Anglo & 1996 \\
\hline At\&T & TCI & Anglo & 1998 \\
\hline Getronics N.V. & Wang Laboratories & Anglo & 1999 \\
\hline Du Pont & Hoechst & Anglo & 1999 \\
\hline AOL & Time Warner & Anglo & 1999 \\
\hline Ford Motor Company & Autonova AB & Anglo & 2000 \\
\hline General Electric Corp. & Honeywell & Anglo & 2000 \\
\hline Ericsson & Ascom & Cont. & 1992 \\
\hline $\mathrm{CCF}$ & $\mathrm{BHF}$ & Cont. & 1994 \\
\hline Siemens & Italtel & Cont. & 1994 \\
\hline Ciba-Geigy & Sandoz & Cont. & 1996 \\
\hline ALSTOM & $\mathrm{ABB}$ & Cont. & 1999 \\
\hline SCA Mölnlycke Holding & Metsä Tissue Corp. & Cont. & 2000 \\
\hline Matra Marconi Space & Astrium & Cont. & 1999 \\
\hline Svedala Industri AB & Metso Corporation & Cont. & 2000 \\
\hline Deutsche Shell GmbH & RWE AG & Cont. & 2001 \\
\hline \multicolumn{4}{|c|}{ Pre-emptive Mergers } \\
\hline AT\&T & Ncr Corporation & Anglo & 1990 \\
\hline Commercial Union & Suez & Anglo & 1994 \\
\hline Gencor & Lonmin & Anglo & 1995 \\
\hline Kimberly-Clark & Scott Paper & Anglo & 1995 \\
\hline Anglo American Corp. & Lonmin & Anglo & 1996 \\
\hline Thyssen Krupp Stahl & Itw Signode & Anglo & 1997 \\
\hline General Electric & Finmeccanica & Anglo & 1998 \\
\hline AT\&T & MediaOne Group & Anglo & 1999 \\
\hline ACCOR S.A. & The BLACKSTONE & Anglo & 1999 \\
\hline Alcoa Inc. & Reynolds Metals & Anglo & 1999 \\
\hline MCI WorldCom & Sprint & Anglo & 1999 \\
\hline Novartis AG & AstraZeneca Plc. & Anglo & 1999 \\
\hline GE Capital Corporation & Heller Financial, Inc & Anglo & 2001 \\
\hline General Electric Company & Unison Industries Inc. & Anglo & 2002 \\
\hline Accor & Wagons-Lits & Cont. & 1991 \\
\hline Shell & Montedison & Cont. & 1993 \\
\hline Knp & Buehrmann Tetterode & Cont. & 1993 \\
\hline
\end{tabular}




\begin{tabular}{|c|c|c|c|}
\hline Acquirer & Target & Sample & Year \\
\hline \multicolumn{4}{|c|}{ Pre-emptive Mergers } \\
\hline Mannesmann & Vlourec Dalmine & Cont. & 1993 \\
\hline Union Carbide & Enichem S.P.A. & Cont. & 1995 \\
\hline Siemens & Lagardere & Cont. & 1996 \\
\hline Cardo & Thyssen & Cont. & 1996 \\
\hline Siemens & Elektrowatt & Cont. & 1997 \\
\hline Schneider & Legrand & Cont. & 2000 \\
\hline De Beers & LVMH & Cont. & 2001 \\
\hline UPM-Kymmene & Haindl & Cont. & 2001 \\
\hline Koninklijke KPN N.V. & E-Plus & Cont. & 2002 \\
\hline Vendex KBB Nederland & Brico Belgium S.A. & Cont. & 2002 \\
\hline \multicolumn{4}{|c|}{ No-Effect Mergers } \\
\hline Ingersoll Rand Co. & Dresser Inc. & Anglo & 1991 \\
\hline Digital Equipment Corp. & Philips Electronics & Anglo & 1991 \\
\hline Chs Electronics Inc. & Metro & Anglo & 1998 \\
\hline Sara Lee & Courtaulds Textiles & Anglo & 2000 \\
\hline Cadbury Schweppes & Pernod & Anglo & 2001 \\
\hline General Electric Company & Unison Industries Inc. & Anglo & 2002 \\
\hline EnerSys & Energy Storage & Anglo & 2002 \\
\hline Tractebel & Synatom & Cont. & 1994 \\
\hline Bertelsmann & Taurus Entertainment & Cont. & 1997 \\
\hline Deutsche Telekom & Bertelsmann & Cont. & 1997 \\
\hline
\end{tabular}




\section{References}

Aguilera, R. V., \& Jackson, G. (2003). The Cross-National Diversity of Corporate Governance: Dimensions and Determinants, Academy of Management Review, 28(3), 447-465.

Akdogu, E. (2003). Value-maximizing managers, value-increasing mergers and overbidding. SSRN Working Paper, Southern Methodist University, Dallas, TX.

Amir, R., Diamantoudi, E, \& Xue, L. (2009). Merger performance under uncertain efficiency gains, International Journal of Industrial Organization, 27, 264 - 273.

Andrade, G., Mitchell, M., \& Stafford, E. (2001). New evidence and perspectives on mergers. Journal of Economic Perspectives, 15, 103-120.

Banerjee, A., \& Eckard, W.E. (1998). Are mega-mergers anti-competitive? Evidence from the first great merger wave. Rand Journal of Economics, 29, 803-827.

Barkema, H. G., \& Schijven, M. (2008). How do firms learn to make acquisitions? A review of past research and an agenda for the future. Journal of Management, 34, 594-634.

Barney, J. B. (1986). Strategic factor markets: expectations, luck, and business strategy. Management Science, 32, 1231-1241.

Barney, J. B. (1988). Returns to bidding firms in mergers and acquisitions: reconsidering the relatedness hypothesis. Strategic Management Journal, 9, 71-78.

Barney, J. B. (1991). Firm Resources and Sustained Competitive Advantage. Journal of Management, 17, $99-120$.

Bergh, D. D. (1997). Predicting divestiture of unrelated acquisitions: An integrative model of Ex Ante conditions. Strategic Management Journal, 18(9), 715-731.

Bergh, D. D. (2001). Executive retention and acquisition outcomes: A test of opposing views on the influence of organizational tenure. Journal of Management, 27, 603-622.

Birkinshaw, J., Bresman, H., \& Håkanson, L. (2000). Managing the post-acquisition integration process: how the human integration and task integration process interact to foster value creation. Journal of Management Studies, 37, 395-425.

Boone, J. (2006). Firms merge in response to constraints. Centre for Economic Policy Research (CEPR) Discussion Paper No. 5744.

Brito, D. (2003). Preemptive mergers under spatial competition. International Journal of Industrial Organization, 21, 1601-1622.

Bruner, R. F. (2002) Does M\&A Pay? A Survey of Evidence for the Decision-Maker. Journal of Applied Finance, 12(1), 7-27. 
Cannella, A.A., \& Hambrick, D.C. (1993). Effects of Executive Departures on the Performance of Acquired Firms. Strategic Management Journal, 14, 137-152.

Capron, L. (1999). The long-term performance of horizontal acquisitions. Strategic Management Journal, 20, 987-1018.

Chatterjee, S. (1986). Types of synergy and economic value: the impact of acquisitions on merging and rival firms. Strategic Management Journal, 7. 119-139.

Chatterjee, S. (1992). Sources of value in takeovers: synergy or restructuring-implications for target and bidder firms. Strategic Management Journal, 13, 267-286.

Chatterjee, S., \& Lubatkin, M. (1990). Corporate mergers, stockholder diversification, and changes in systematic risk. Strategic Management Journal, 11, 255-268.

Chen, M. (1996). Competitor analysis and inter-firm rivalry: Toward a theoretical integration. Academy of Management Review, 21, 100-134.

Clougherty, J.A., \& Duso, T. (2009). The impact of horizontal mergers on rivals: gains to being left outside a merger. Journal of Management Studies, 46(8), 1365-1395.

Clougherty, J.A., \& Moliterno, T.P. (2010). Empirically eliciting complementarities in capabilities: integrating quasi-experimental and panel data methodologies. Strategic Organization, 8(2), $107-$ 131.

Datta, D. K. (1991). Organizational fit and M\&A performance: effects of post-M\&A integration. Strategic Management Journal, 12, 281-297.

Datta, D. K., Pinches, G. E. \& Narayanan, V. K. (1992). Factors influencing wealth creation from mergers and acquisitions: a meta-analysis. Strategic Management Journal, 13, 67-84.

Deneckere, R., \& Davidson, C. (1985). Incentives to form coalitions with Bertrand competition. Rand Journal of Economics, 16, 473-486.

Dierickx, I., \& Cool, K. (1989). Asset stock accumulation and sustainability of competitive advantage. Management Science, 35, 1504-1510.

Duso, T., Gugler, K., \& Yurtoglu, B. (2010). Is the event study methodology useful for merger analysis. International Review of Law and Economics, 30, 186-192.

Duso, T., Neven, D., \& Röller, L.H. (2007). The political economy of European merger control: Evidence using stock market data. Journal of Law and Economics, 50(3), 455-489.

Eckbo, B. E. (1983). Horizontal mergers, collusion, and stockholder wealth. Journal of Financial Economics, 11, 241-273.

Ellert, J. (1976). Mergers, antitrust law enforcement and stockholder returns. Journal of Finance, 31 (2), 715-732. 
Farrell, J., \& Shapiro, C. (1990). Horizontal mergers: An equilibrium analysis. The American Economic Review, 80 (1), 107-126.

Fee, C. E., \& Thomas, S. (2004). Sources of gains in horizontal mergers: evidence from customer, supplier, and rival firms. Journal of Financial Economics, 74, 423-460.

Flanagan, D.J. (1996). Announcements of purely related and purely unrelated mergers and shareholder returns: Reconciling the relatedness paradox. Journal of Management, 22(6), 823835.

Fosfuri, A., \& Giarratanal, M.S. (2009). Masters of war: Product innovation and new advertising in mature product markets. Management Science, 55(2), 181-191.

Fridolfsson, S.-O. \& Stennek, J. (2005). Why mergers reduce profits, and raise share prices - a theory of preemptive mergers. Journal of the European Economic Association, 3(5), 1083-104.

Gimeno, J. \& Woo, C. Y. (1999). Multimarket contact, economies of scope, and firm performance. Academy of Management Journal, 43(3), 239-259.

Gugler, K., Mueller, D.C., \& Yurtoglu, B.B. (2004). Corporate Governance and the Returns on Investment. Journal of Law and Economics, 47, 589-633.

Haleblian, J., Devers, C.E., McNamara, G., Carpenter, M.A., \& Davison, R.B. (2009). Taking stock of what we know about mergers and acquisitions: A review and research agenda. Journal of Management, 55(2), 469-502.

Hall, P., \& Soskice, D. (2001). Varieties of Capitalism. The Institutional Foundations of Comparative Advantage. Oxford University Press, Oxford.

Haspeslagh, P., \& Jemison, D. (1991). Managing acquisitions: Creating value through corporate renewal. Free Press, New York.

Hill, C.W.L.. (2011). International Business: Competing in the global marketplace. McGraw-Hill Irwin, New York.

Hitt, M. A., Harrison, J. S., \& Ireland, R. D. (2001). Mergers and acquisitions: A guide to creating value for shareholders. Oxford University Press, Oxford.

Jemison, D. B., \&. Sitkin, S. B. (1986). Corporate acquisitions: a process perspective. Academy of Management Review, 11, 145-163.

Ketchen, D. J., Boyd, B. K. \& Bergh, D. D. (2008). Research methodology in strategic management: Past accomplishments and future challenges. Organizational Research Methods, 11(4), 643-658.

Kim, E. H., \& Singal, V. (1993). Mergers and market power: Evidence from the airline industry. American Economic Review, 83, 549-570. 
King, D. R., Dalton, D. R., Daily, C. M., \& Covin, J. G. (2004). Meta-analysis of post-acquisition performance: indications of unidentified moderators. Strategic Management Journal, 25, 187-200.

Larsson, R., \& Finkelstein, S. (1999). Integrating strategic, organizational, and human resource perspectives on mergers and acquisitions: a case study of synergy realization. Organization Science, 10, 1-26.

Larsson, R., \& Lubatkin, M. (2001). Achieving acculturation in mergers and acquisitions: an international case study. Human Relations, 54, 1573-1607.

Long, J.S. (1987). A graphical method for the interpretation of multinomial logit analysis. Sociological Methods Research, 15(4), 420-446.

Lubatkin, M. (1983). Mergers and the performance of the acquiring firm. Academy of Management Review, 8, 218-225.

Lubatkin, M. (1987). Merger strategies and stockholder value. Strategic Management Journal, 8, 39-53.

Lubatkin, M., \& Lane, P. J. (1996). Psst... the merger mavens still have it wrong! Academy of Management Executive, 10, 21-37.

Lubatkin, M., Srinivasan, N., \& Merchant, H. (1997). Merger strategies and shareholder value during times of relaxed antitrust enforcement: the case of large mergers during the 1980s. Journal of Management, 23, 59-81.

McGahan, A. M., \& Silverman, B. S. (2006). Profiting from technological innovation by others: The effect of competitor patenting on firm value. Research Policy, 35(8), 1222-1242.

McWilliams, A., \& Siegel, D. (1997). Event studies in management research: theoretical and empirical issues. Academy of Management Journal, 40, 626-657.

McWilliams, A., Siegel, D. \& Teoh S. H. (1999). Issues in the use of the event study methodology: A critical analysis of corporate social responsibility studies. Organizational Research Methods, 2(4), 340-365.

Michel, A., \& Shaked, I. (1985). Evaluating merger performance. California Management Review, 27, 109-118.

Moeller, S. B., Schlingemann, F. P., \& Stulz, R. M. (2005). Wealth distribution on a massive scale? A study of Acquiring-Firm Returns in the Recent Merger Wave. Journal of Finance, 60(2), 757 782.

Molnar, J. (2007). Preemptive Horizontal Mergers: Theory and Evidence. Working Paper, Northwestern University, Chicago, IL.

Mueller, D. C. (1969). A theory of conglomerate mergers. Quarterly Journal of Economics, 83, 643-659. 
Newbert, S. (2007). Empirical Research on the Resource-Based View of the Firm: An Assessment and Suggestions for Future Research. Strategic Management Journal, 28(2), 121-46.

Oxley, J. E., Sampson, R. C., \& Silverman, B. S. (2009). Arms race or détente? How inter-firm alliance announcements change the stock market valuation of rivals. Management Science, 55(8), $1321-1337$.

Pablo, A. L. (1994). Determinants of acquisition integration level: a decision making perspective. Academy of Management Journal, 37, 803-836.

Palepu, K. (1985). Diversification strategy, profit performance and the entropy measure. Strategic Management Journal, 6, 239-255.

Perry, M. K., \& Porter, R. H. (1985). Oligopoly and the incentive for horizontal merger. The American Economic Review, 75 (1), 219-227.

Peteraf, M. A. (1993). The cornerstones of competitive advantage: a resource-based view. Strategic Management Journal, 14, 179-191.

Pettigrew, A. (1977). Strategy formulation as a political process. Journal of International Management Studies, 7, 78-87.

Porter, M. E. (1985). Competitive Advantage. Free Press, New York.

Prahalad, C. K., \& Bettis, R. A. (1986). The dominant logic: a new linkage between diversity and performance. Strategic Management Journal, 7, 485-501.

Roll, R. (1986). The hubris hypothesis of corporate takeovers. Journal of Business, 59, 197-216.

Rumelt, R. P. (1974). Strategy, Structure and Economic Performance. Harvard University Press, Boston, MA.

Salant, S., Switzer, S., \& Reynolds, R.J. (1983). Losses from horizontal merger: The effects of an exogenous change in industry structure on Cournot-Nash equilibrium. Quarterly Journal of Economics, 98, 185-199.

Scholes, M., \& Williams, J. (1977). Estimating beta from non-synchronous data. Journal of Financial Economics, 5, 309-327.

Seth, A. (1990). Sources of value creation in acquisitions: an empirical investigation. Strategic Management Journal, 11, 431-446.

Shahrur, H. (2005). Industry structure and horizontal takeovers: analysis of wealth effects on rivals, suppliers, and corporate customers. Journal of Financial Economics, 76, 61-98.

Simon, H. A. (1957). Models of Man. Social and Rational. Wiley, New York. 
Singh, H., \& Montgomery, C. (1987). Corporate acquisition strategies and economic performance. Strategic Management Journal, 8, 377-386.

Sirower, M. L. (1997). The synergy trap: how companies lose the acquisition game. Free Press, New York.

Song, M. H., \& Walkling, R. A. (2000). Abnormal returns to rivals of acquisition targets: a test of the acquisition probability hypothesis. Journal of Financial Economics, 55, 143-171.

Stigler, G. J. (1964). A theory of oligopoly. Journal of Political Economy, 72, 44-61

Tirole, J. (1992). The theory of industrial organization. MIT Press, Cambridge.

Trautwein, F. (1990). Merger motives and merger prescriptions. Strategic Management Journal, 11, 283296.

Vermeulen, F., \& Barkema, H. (2001). Learning through acquisitions. Academy of Management Journal, 44, 457-476.

Walsh, J. P. (1988). Top management turnover following acquisitions. Strategic Management Journal, 9 , 173-183.

Walter, G. A., \& Barney, J. B. (1990). Management objectives in mergers and acquisitions. Strategic Management Journal, 11, 79-86.

Weidenbaum, M., \& Vogt, S. (1987). Takeovers and stockholders: winners and losers. California Management Review, 29(4), 157-167.

Zhang, Y., \& Gimeno, J. (2010). Earnings pressure and competitive behaviour: Evidence from the U.S. electricity industry. Academy of Management Journal, 53(4), 743-768. 
Table 1

Simple Merger Taxonomy

\begin{tabular}{cc}
\hline $\begin{array}{c}\text { Merging Firms } \\
\text { Gain }\end{array}$ & $\begin{array}{c}\text { Merging Firms } \\
\text { Lose }\end{array}$ \\
\hline $\begin{array}{c}\text { Value-enhancing } \\
\text { Mergers }\end{array}$ & $\begin{array}{c}\text { Value-decreasing } \\
\text { Mergers }\end{array}$ \\
\hline
\end{tabular}


Table 2

Proposed Merger Taxonomy

\begin{tabular}{lcc}
\hline & $\begin{array}{c}\text { Merging Firms } \\
\text { Gain }\end{array}$ & $\begin{array}{c}\text { Merging Firms } \\
\text { Lose }\end{array}$ \\
\hline $\begin{array}{l}\text { Rivals } \\
\text { Gain }\end{array}$ & $\begin{array}{c}\text { Collusion-based } \\
\text { Synergistic Mergers } \\
\text { (Competitive-Complements) }\end{array}$ & $\begin{array}{c}\text { Non-synergistic } \\
\text { Mergers } \\
\text { (Competitive-Substitutes) }\end{array}$ \\
\hline Rivals & $\begin{array}{c}\text { Efficiency-based } \\
\text { Synergistic Mergers } \\
\text { (Competitive-Substitutes) }\end{array}$ & $\begin{array}{c}\text { Pre-emptive } \\
\text { Mergers }\end{array}$ \\
\hline
\end{tabular}


Table 3

The Means for the Estimated CARs

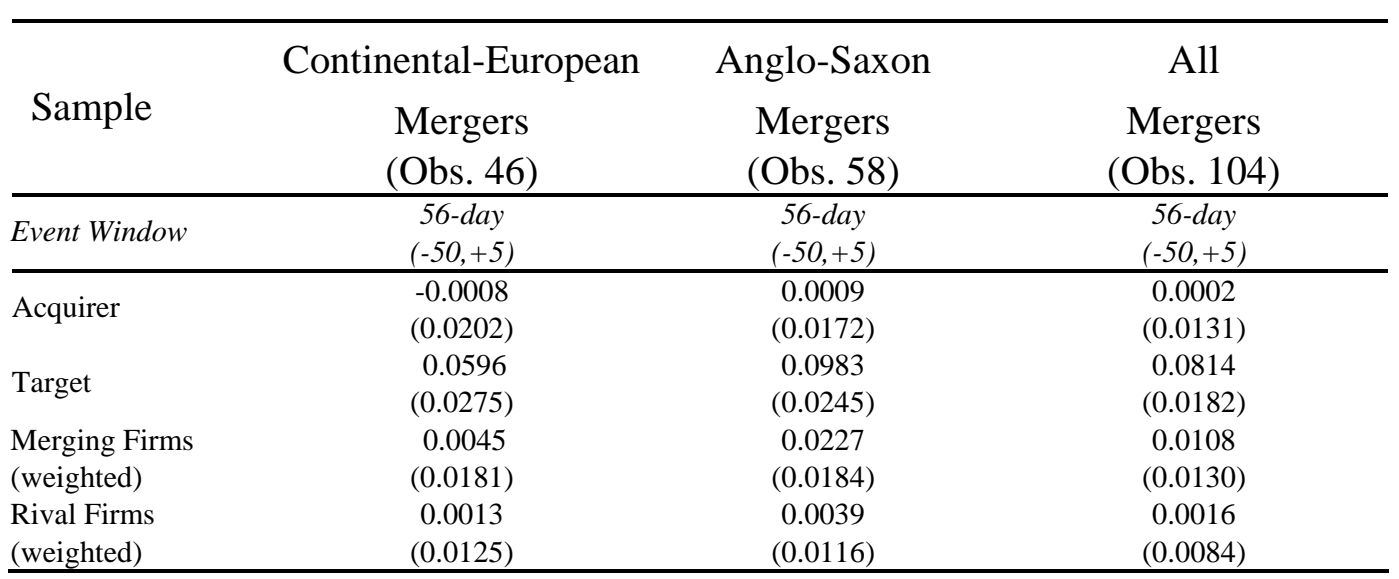

Notes: The mean value of the average estimated CAR employing the 56-day window $(50,5)$ is reported in the first line, and standard errors are reported on the second line in parentheses. For merging firms and rival firms, the individual CARs are weighted with the respective market value. 
Table 4

Merger Taxonomy for Anglo-Saxon Mergers

\begin{tabular}{|c|c|c|c|c|}
\hline & $\begin{array}{l}\text { Merging Firms } \\
\text { Gain }\end{array}$ & $\begin{array}{l}\text { Merging Firms } \\
\text { No-Effect }\end{array}$ & $\begin{array}{l}\text { Merging Firms } \\
\text { Lose }\end{array}$ & Total \\
\hline $\begin{array}{l}\text { Rivals } \\
\text { Gain }\end{array}$ & $\begin{array}{c}13(22.41 \%) \\
\text { Collusion-based } \\
\text { Synergistic Mergers }\end{array}$ & $3(5.17 \%)$ & $\begin{array}{c}9(15.52 \%) \\
\text { Non-synergistic } \\
\text { Mergers }\end{array}$ & 25 (43.10\%) \\
\hline $\begin{array}{l}\text { Rivals } \\
\text { No-Effect }\end{array}$ & $0(0.00 \%)$ & $0(0.00 \%)$ & $3(5.17 \%)$ & 3 (5.17\%) \\
\hline $\begin{array}{l}\text { Rivals } \\
\text { Lose }\end{array}$ & $\begin{array}{c}15(25.86 \%) \\
\text { Efficiency-based } \\
\text { Synergistic Mergers }\end{array}$ & $1(1.72 \%)$ & $\begin{array}{c}14(24.14 \%) \\
\text { Pre-emptive } \\
\text { Mergers }\end{array}$ & $30(51.72 \%)$ \\
\hline Total & 28 (48.28\%) & $4(6.90 \%)$ & $26(44.83 \%)$ & $58(100 \%)$ \\
\hline
\end{tabular}

Notes: We measure profitability by means of the 56-day CAR window. The first number in each cell reflects how many such merger-type observations are in the sample, while the second number - in parentheses - refers to the percentage of all observations the cell represents. 
Table 5

Merger Taxonomy for Continental-European Mergers

\begin{tabular}{lcccc}
\hline & $\begin{array}{c}\text { Merging Firms } \\
\text { Gain }\end{array}$ & $\begin{array}{c}\text { Merging Firms } \\
\text { No-Effect }\end{array}$ & $\begin{array}{c}\text { Merging Firms } \\
\text { Lose }\end{array}$ & Total \\
\hline $\begin{array}{l}\text { Rivals } \\
\text { Gain }\end{array}$ & $\begin{array}{c}13(28.26 \%) \\
\text { Collusion-based } \\
\text { Synergistic Mergers }\end{array}$ & $1(2.17 \%)$ & $\begin{array}{c}9(19.57 \%) \\
\text { Non-synergistic } \\
\text { Mergers }\end{array}$ & $23(50.00 \%)$ \\
\hline Rivals & $1(2.17 \%)$ & $0(0.00 \%)$ & $1(2.17 \%)$ & $2(4.35 \%)$ \\
No-Effect & & & & \\
\hline Rivals & $8(17.39 \%)$ & $0(0.00 \%)$ & $13(28.26 \%)$ & $21(45.65 \%)$ \\
Lose & Efficiency-based & & Pre-emptive & \\
& Synergistic Mergers & & Mergers & \\
\hline Total & $22(47.83 \%)$ & $1(2.17 \%)$ & $23(50.00 \%)$ & $46(100 \%)$ \\
\hline
\end{tabular}

Notes: We measure profitability by means of the 56-day CAR window. The first number in each cell reflects how many such merger-type observations are in the sample, while the second number - in parentheses - refers to the percentage of all observations the cell represents. 
Bücher des Schwerpunkts Märkte und Politik

Books of the Research Area Markets and Politics

Kai A. Konrad, Holger Zschäpitz

Schulden ohne Sühne: Warum der Absturz der Staatsfinanzen uns alle trifft 2010, C. H. Beck

Kai A. Konrad, Tim Lohse (Eds.)

Einnahmen- und Steuerpolitik in Europa:

Herausforderungen und Chancen

2009, Peter Lang Verlag

Kai A. Konrad

Strategy and Dynamics in Contests

2009, Oxford University Press

Roger D. Congleton, Arye L. Hillman, Kai A. Konrad

(Eds.)

40 Years of Research on Rent Seeking

2008, Springer

Kai A. Konrad, Beate Jochimsen (Eds.)

Föderalismuskommission II:

Neuordnung von Autonomie und Verantwortung

2008, Peter Lang Verlag

Mark Gradstein, Kai A. Konrad (Eds.)

Institutions and Norms in Economic Development 2007, MIT Press

Johannes Münster

Mobbers, Robbers, and Warriors

2007, Shaker Verlag

Kai A. Konrad, Beate Jochimsen (Eds.)

Der Föderalstaat nach dem Berlin-Urteil

2007, Peter Lang Verlag

Kai A. Konrad, Beate Jochimsen (Eds.)

Finanzkrise im Bundesstaat

2006, Peter Lang Verlag

Robert Nuscheler

On Competition and Regulation in Health Care

Systems

2005, Peter Lang Verlag

Pablo Beramendi

Decentralization and Income Inequality

2003, Madrid: Juan March Institute

Thomas R. Cusack

A National Challenge at the Local Level: Citizens, Elites and Institutions in Reunified Germany

2003, Ashgate

Sebastian Kessing

Essays on Employment Protection

2003, Freie Universität Berlin

http://www.diss.fu-berlin.de/2003/202

Daniel Krähmer

On Learning and Information in Markets and

Organizations

2003, Shaker Verlag
Tomaso Duso

The Political Economy of the Regulatory Process: An Empirical Approach

Humboldt-University Dissertation, 2002, Berlin, http://edoc.hu-berlin.de/dissertationen/duso-tomaso2002-07-17/PDF/Duso.pdf

\section{Bob Hancké}

Large Firms and Institutional Change. Industrial Renewal and Economic Restructuring in France 2002, Oxford University Press

Andreas Stephan

Essays on the Contribution of Public Infrastructure to Private: Production and its Political Economy

2002, dissertation.de

Peter A. Hall, David Soskice (Eds.)

Varieties of Capitalism

2001, Oxford University Press

Hans Mewis

Essays on Herd Behavior and Strategic Delegation 2001, Shaker Verlag

Andreas Moerke

Organisationslernen über Netzwerke - Die

personellen Verflechtungen von Führungsgremien

japanischer Aktiengesellschaften

2001, Deutscher Universitäts-Verlag

Silke Neubauer

Multimarket Contact and Organizational Design

2001, Deutscher Universitäts-Verlag

Lars-Hendrik Röller, Christian Wey (Eds.)

Die Soziale Marktwirtschaft in der neuen

Weltwirtschaft, WZB Jahrbuch 2001

2001, edition sigma

Michael Tröge

Competition in Credit Markets: A Theoretic

Analysis

2001, Deutscher Universitäts-Verlag

Torben Iversen, Jonas Pontusson, David Soskice

(Eds.)

Unions, Employers, and Central Banks

2000, Cambridge University Press

Tobias Miarka

Financial Intermediation and Deregulation:

A Critical Analysis of Japanese Bank-Firm-

Relationships

2000, Physica-Verlag 
Áron Kiss Coalition Politics and Accountability

Benny Geys Friedrich Heinemann

Alexander Kalb

Salmai Qari

Kai A. Konrad

Benny Geys

Kai A. Konrad Salmai Qari

Sven Chojnacki

Nils Metternich Johannes Münster

Oliver Gürtler Johannes Münster

Dan Kovenock

Brian Roberson

Subhasish M.

Chowdhury

Dan Kovenock

Roman M. Sheremeta

Michael R. Baye

Dan Kovenock Casper G. de Vries

Florian Morath Johannes Münster

Benny Geys

Paolo Buccirossi

Lorenzo Ciari

Tomaso Duso

Giancarlo Spagnolo

Cristiana Vitale

Pedro P. Barros Joseph Clougherty

Jo Seldeslachts

Paolo Buccirossi

Lorenzo Ciari

Tomaso Duso

Giancarlo Spagnolo

Cristiana Vitale

Paolo Buccirossi

Lorenzo Ciari

Tomaso Duso

Giancarlo Spagnolo

Cristiana Vitale

Municipalities Tax Compliance

Mercenaries in Civil Wars, 1950-2000

Sabotage in Dynamic Tournaments

Outcomes

Games

Contests with Rank-Order Spillovers

Information Acquisition in Conflicts

Wars, Presidents and Popularity:

An empirical assessment Policy: Frequency or Composition?

Deterrence in Competition Law
Voter Involvement, Fiscal Autonomy and Public

Sector Efficiency: Evidence from German

Patriotism, Taxation and International Mobility

The Last Refuge of a Scoundrel? Patriotism and

Non-Partisan 'Get-Out-the-Vote' Efforts and Policy

An Experimental Investigation of Colonel Blotto

The Political Cost(s) of War Re-examined

Competition policy and productivity growth:

How to Measure the Deterrence Effects of Merger

Measuring the deterrence properties of competition policy: the Competition Policy Indexes
SP || $2009-05$

SP || $2009-06$

SP II $2009-09$

SP || $2009-10$

SP I| $2009-14$

SP I| $2009-01$

SP || 2009-02

SP II $2009-03$

SP II $2009-04$

SP || $2009-07$

SP || $2009-08$

SP || $2009-11$

SP II $2009-12$

SP || $2009-13$

SP II $2009-15$ 
Talat Mahmood The Decision to Migrate: A Simultaneous Decision

SP || $2009-17$ Klaus Schömann Making Approach 
Dorothea Kübler

Dietmar Fehr

Dorothea Kübler

David Danz

Alastair R. Beresford

Dorothea Kübler

Sören Preibusch

Julia Schmid

Dietmar Fehr

Benny Geys

Margarita Kalamova

Kai A. Konrad

Kai A. Konrad

Florian Morath

Wieland Müller

Kai A. Konrad

Benny Geys

Kai A. Konrad

Kai A. Konrad

Kai A. Konrad

Rabah Amir Natalia Lazzati

Joseph A Clougherty

Tomaso Duso
Experimental Practices in Economics:

Performativity and the Creation of Phenomena

Information and Beliefs in a Repeated

Normal-form Game

Unwillingness to Pay for Privacy:

A Field Experiment

Exclusion in the All-Pay Auction: An Experimental Investigation

War Casualties and US Presidential Popularity: A Comparison of the Korean, Vietnam and Iraq War

Nation Brands and Foreign Direct Investment

Taxation and Market Power

SP || $2010-01$

SP I| $2010-02$

SP || $2010-03$

SP || $2010-04$

SP II $2010-05$

SP || $2010-06$

SP || $2010-07$

Merger Profitability in Industries with Brand Portfolios and Loyal Customers

SP || $2010-08$

Federalism and Optimal Allocation Across Levels of Governance

Dynamic Contests

Search Costs and Corporate Income Tax

Competition

Network Effects, Market Structure and Industry

Performance

Using Rival Effects to Identify Synergies and Improve Merger Typologies
SP || $2010-10$

SP || $2010-11$

SP || $2010-09$

SP || $2010-12$

SP || $2010-13$ 
Bei Ihren Bestellungen von WZB-Papers schicken

Sie bitte unbedingt einen an Sie adressierten Auf-

kleber mit sowie je paper eine Briefmarke im Wert

von 0,51 Euro oder einen "Coupon Reponse Inter-

national " (für Besteller aus dem Ausland)
Please send a self addressed label and postage stamps in the amount of 0.51 Euro or a "CouponReponse International" (if you are ordering from outside Germany) for each WZB-paper requested

Absender I Return Address:

Wissenschaftszentrum Berlin

für Sozialforschung

Presse- und Informationsreferat

Reichpietschufer 50

D-10785 Berlin-Tiergarten

Hiermit bestelle ich folgende(s) Discussion paper(s):

Please send me the following Discussion paper(s):

Bestell-Nr. I Order no.

Autor/in, Kurztitel /Author(s) / Title(s) in brief 